\title{
INTERNAL FIXATION OR HEMIARTHROPLASTY FOR UNDISPLACED FRACTURES OF THE FEMORAL NECK IN OCTOGENARIANS
}

\author{
A. C. W. HUI, G. H. ANDERSON, R. CHOUDHRY, J. BOYLE, P. J. GREGG
}

From Leicester Royal Infirmary, England

We compared the reoperation rate after internal fixation for minimally displaced or impacted intracapsular fractures of the femoral neck in patients aged 80 years and above with that in similar patients aged 65 to 79 years. We also compared the results of internal fixation with those of hemiarthroplasty for displaced intracapsular fracture in an age- and sex-matched group of elderly patients.

We found that a significantly greater proportion of the older patients treated by internal fixation required reoperation than either the younger group or the age-matched group treated by hemiarthroplasty. Our results indicate that internal fixation may not be the best treatment for extremely elderly patients with minimally displaced or impacted intracapsular fractures of the femoral neck.

J Bone Joint Surg [Br] 1994; 76-B:891-4.

Received 10 November 1993; Accepted after revision 22 March 1994

It is generally accepted that undisplaced fractures of the femoral neck (Garden stages 1 or 2) should be treated by internal fixation to allow early mobilisation without secondary displacement (Bentley 1968; Barnes et al 1976). This seems logical for relatively young patients, but in very elderly patients severe osteopenia and other age-related conditions may make internal fixation less suitable. Bone density has been found to correlate with the security of fixation (Swiontkowski et al 1987) and it has been shown that the severe osteopenia sometimes

A. C. W. Hui, FRCS, Orthopaedic Registrar

G. H. Anderson, FRCS, Senior Orthopaedic Registrar

J. Boyle, MB ChB, Senior House Officer in Orthopaedic Surgery

Leicester Royal Infirmary NHS Trust, Infirmary Square, Leicester LE1 5WW, UK.

R. Choudhry, MCh Orth, Orthopaedic Surgeon

203 Keshaw Chambers, Lalgate, Surat 395001, India.

P. J. Gregg, MD, FRCS, Professor of Orthopaedic Surgery

University Department of Orthopaedic Surgery, Glenfield General Hospital, Groby Road, Leicester LE3 9QP, UK.

Correspondence should be sent to Mr G. H. Anderson.

C)1994 British Editorial Society of Bone and Joint Surgery

0301-620X/94/6852\$2.00 seen in rheumatoid arthritis is a contraindication to internal fixation (Martinez 1993). The experience of surgeons performing hemiarthroplasties on octogenarian patients is that the femoral head is often only a thin shell containing cancellous bone of very poor quality, which is unlikely to provide any fixation device with sufficient purchase to resist the large forces transmitted along the femoral neck (Freeman, Todd and Pirie 1974).

The effect of extreme old age on the management of undisplaced intracapsular femoral neck fractures has not been specifically studied. Raaymakers and Marti (1991) reported 170 patients treated conservatively and found that the risk of secondary displacement increased with age. Very elderly patients may constitute a distinct group which needs more careful evaluation. We have assessed the place of internal fixation for this group of patients.

\section{PATIENTS AND METHODS}

Since January 1991 we have recorded in a specially designed database details of all patients with proximal femoral fractures admitted to the Leicester Royal Infirmary. Of the 976 patients there were 57 aged over 64 years of age with undisplaced femoral neck fractures who had been followed up for a minimum of six months. Of these, 29 were aged 80 years or more $(50.9 \%)$. The large proportion of octogenarians probably reflects the general increase in the elderly population of the UK.

All 29 octogenarians had been treated by internal fixation with a sliding hip screw and a two-hole plate; they constitute group 1 of our study, and their records and radiographs were reviewed and compared with those of two other groups. Group 2 consists of patients aged from 65 to 79 years treated by internal fixation for undisplaced intracapsular fractures. Group 3 was selected from the database of those who had had hemiarthroplasty for displaced intracapsular femoral neck fractures as age- and sex-matched controls for group-1 patients. We were able to find two control subjects for each patient in group 1 . Details of the three groups are given in Table I; the outcome of treatment was unknown to the author who carried out the selections for group 3.

Dementia has been shown to be an important prognostic indicator for hip fracture (Evans, Wandless 
and Prudham 1980; Wood et al 1992); all our patients had a mental function test on admission. It was not possible to match patients and control subjects with respect to mental test score as well as age and sex but the overall distributions of scores within the groups 1 and 3 were similar, using the Kruskal-Wallis test.

Of the 114 patients studied, $31(27 \%)$ had died and $29(25 \%)$ were not available for review. The remaining 54 patients (48\%) were reviewed by an independent assessor who was unaware of the groupings.
Table I. Number and percentages of patients in the three groups

\begin{tabular}{lcll}
\hline & $\begin{array}{l}\text { Group 1 } \\
\text { Over 80 years } \\
\text { Internal fixation }\end{array}$ & $\begin{array}{l}\text { Group 2 } \\
\text { 65 to 79 years } \\
\text { Internal fixation }\end{array}$ & $\begin{array}{l}\text { Group 3* } \\
\text { Over 80 years } \\
\text { Hemiarthroplasty }\end{array}$ \\
\hline Died & $5(17)$ & $7(25)$ & $19(33)$ \\
Reviewed & $15(52)$ & $16(57)$ & $23(41)$ \\
Not reviewed & $9(31)$ & $5(18)$ & $15(26)$ \\
Total & $29(100)$ & $28(100)$ & $57(100)$ \\
\hline
\end{tabular}

* matched for age and gender with group 1

Table II. Details of failure of treatment in the three groups

\begin{tabular}{|c|c|c|c|c|c|c|}
\hline Group & Case & $\begin{array}{l}\text { Age } \\
(\mathbf{y r})\end{array}$ & Associated illness & Failure & Second operation & Final outcome \\
\hline \multirow[t]{9}{*}{ Group 1} & 1 & 89 & None & Secondary displacement & Thompson hemiarthroplasty & \\
\hline & 2 & 90 & Carcinoma breast, Parkinson's disease & Avascular necrosis & $\begin{array}{l}\text { Austin Moore } \\
\text { hemiarthroplasty }\end{array}$ & \\
\hline & 3 & 83 & Partial thyroidectomy & $\begin{array}{l}\text { Varus position led to cutting-out of } \\
\text { screw }\end{array}$ & Total hip arthroplasty & $\begin{array}{l}\text { Dislocation } \\
\text { Girdlestone arthroplasty }\end{array}$ \\
\hline & 4 & 89 & Hypothyroidism & Secondary displacement & & \\
\hline & 5 & 92 & Hemiparesis & Screw protrusion & Removal of screw & \\
\hline & 6 & 90 & None & Secondary displacement & $\begin{array}{l}\text { Monk bipolar } \\
\text { hemiarthroplasty }\end{array}$ & \\
\hline & 7 & 81 & None & $\begin{array}{l}\text { Superior placement of screw led to } \\
\text { cutting-out }\end{array}$ & Total hip arthroplasty & \\
\hline & 8 & 85 & None & $\begin{array}{l}\text { Femoral head displaced during } \\
\text { operation, subsequent failure of } \\
\text { fixation }\end{array}$ & Total hip arthroplasty & \\
\hline & 9 & 93 & None & Secondary displacement & Thompson hemiarthroplasty & \\
\hline \multirow[t]{2}{*}{ Group 2} & 1 & 66 & None & Subtrochanteric fracture & Sliding screw-plate & $\begin{array}{l}\text { Converted to THR, } \\
\text { which dislocated } \\
\text { Girdlestone arthroplasty }\end{array}$ \\
\hline & 2 & 69 & None & Displacement of fracture after a fall & Total hip arthroplasty & \\
\hline \multirow[t]{4}{*}{ Group 3} & 1 & 83 & Coronary artery disease & Pneumonia, deep infection & $\begin{array}{l}\text { Infected prosthesis removed } \\
\text { to Girdlestone arthroplasty }\end{array}$ & Died at 2 months \\
\hline & 2 & 90 & None & Dislocation & $\begin{array}{l}\text { Manipulation under } \\
\text { anaesthesia }\end{array}$ & Died at 14 months \\
\hline & 3 & 87 & $\begin{array}{l}\text { Non-insulin-dependent diabetes, } \\
\text { hypertension }\end{array}$ & Dislocation & $\begin{array}{l}\text { Manipulation under } \\
\text { anaesthesia }\end{array}$ & \\
\hline & 4 & 92 & None & $\begin{array}{l}\text { Fractured greater trochanter, central } \\
\text { protrusion of prosthesis }\end{array}$ & Bed-rest & Died at 6 months \\
\hline
\end{tabular}

\section{RESULTS}

Nine patients from group $1(31 \%)$ had required reoperation or readmission for local complications related to the fracture, compared with two $(7 \%)$ from group $2(\mathrm{p}=0.026$, chi-squared test) and four (7\%) from group $3(p=0.01$, chi-squared test). Table II lists the details of these failures. The mortality rate at three months was $14 \%$ in group 1 , $18 \%$ in group 2 and $17 \%$ in group 3, insignificant differences by the chi-squared test. The mean acute hospital stay for the initial admission was 16.3 days ( 3 to
37 , SD 8.8 ) for group $1,13.3$ days ( 3 to 23 , SD 6.0 ) for group 2 and 15.7 days ( 2 to 51 , SD 10.9 ) for group 3. Again, there was no significant difference between the three groups ( $t$-test).

The incidence of pain in the survivors of the three groups (Table III) showed no significant difference between groups 1 and $2(p=0.525)$ or between groups 1 and $3(p=0.58$, Fisher's exact test).

Our main finding was that nine of the 29 patients in group 1 had required a second operation. Of these nine failures, three could be attributed to technical errors: one 
Table III. Incidence of pain in the survivors who were reviewed

\begin{tabular}{llll}
\hline & $\begin{array}{l}\text { Group 1 } \\
\text { Over 80 years } \\
\text { Internal fixation }\end{array}$ & $\begin{array}{l}\text { Group 2 } \\
\text { 65 to 79 years } \\
\text { Internal fixation }\end{array}$ & $\begin{array}{l}\text { Group 3 } \\
\text { Over 80 years } \\
\text { Hemiarthroplasty }\end{array}$ \\
\hline No pain or mild pain & 14 & 14 & 22 \\
Moderate or severe pain & 1 & 2 & 1 \\
\hline
\end{tabular}

screw was placed in the superior part of the femoral head and cut out and two other fractures became displaced either before or during internal fixation. One of these displaced into varus, and the other had rotational displacement during the placement of the lag screw, despite the use of a second, anti-rotation, guide wire. Most of the operations had been performed by a hipfracture research fellow and the remainder by surgeons of registrar grade or above. We believe that the level of expertise was representative of that in other UK hospitals.

We could identify no technical errors in the other six failures in group 1. In four patients the screw was well placed but did not appear to provide sufficient purchase on the femoral head, allowing secondary displacement. In one patient avascular necrosis of the femoral head led to cutting-out of the screw and in the sixth patient the screw protruded into the joint after successful union of the fracture.

In group 2, the younger patients with undisplaced fractures treated by internal fixation, only two patients had required reoperation. One, early in the series, had a Garden stage-1 fracture treated with three cannulated screws and sustained an ipsilateral subtrochanteric fracture before the intracapsular fracture had united. Internal fixation of both fractures using a sliding screw plate was unsuccessful, and conversion to total hip replacement was followed by recurrent dislocation and finally, an excision arthroplasty. Since then we have fixed all intracapsular fractures with a sliding hip screw and a two-hole plate. The second revision was for fracture displacement after a serious fall. Total hip replacement was successful.

Of the 58 patients in group 3 , with displaced fractures treated by hemiarthroplasty, four have required readmission and only one required reoperation, for removal of the prosthesis for deep infection. Two required closed reductions for dislocations, which were successful. The other patient, who had gross osteoporosis after an earlier pelvic fracture had acute protrusion of a Thompson prosthesis through the medial wall of the acetabulum. A period of bed-rest enabled her to be mobilised on a Zimmer frame and discharged back to a residential home.

\section{DISCUSSION}

Our failure rate after the internal fixation of a minimally displaced or impacted intracapsular fracture in patients aged 80 years or more was similar to that reported after conservative treatment by Raaymakers and Marti (1991).
It appears therefore that internal fixation in patients of this age does not greatly alter the stability of these fractures. Clark, Crofts and Saleh (1990) found that the earliest sign of failure was impaction of the femoral neck, which suggests that the implant could not carry the load at the fracture gap. Two of our patients probably had displacement during the course of fixation although great care was taken in positioning and an antirotation pin was used during reaming and screw insertion. We found no such displacements in group 2; this difference may reflect the increasing tendency to secondary displacement in very elderly patients (Raaymakers and Marti 1991).

In our group-2 patients, the failure rate is in the range reported by other authors (Garden 1961; Bentley 1968; Barnes et al 1976; Strömqvist et al 1987): the high failure rate found in group 1 does seem to be related to age. Bone density decreases with age (Law, Wald and Meade 1991) and the relationship between fixation failures and age is probably mediated by increasingly severe osteoporosis (Swiontkowski, Hansen and Kellam 1984). None of the five male patients in group 1 suffered fixation failure, but the difference in outcome between male and female patients is not statistically significant due to the small numbers. The mean bone density in males at all ages, however, is greater than that in females (Law et al 1991).

Excellent results have been reported for the internal fixation of impacted or minimally displaced fractures of the femoral neck in patients over 80 years of age (Barnes et al 1976; Strömqvist et al 1987) but ours were worse. Strömqvist et al (1987) reported a female to male ratio of 2.6 to 1 , considerably lower than that usually reported for UK patients, and there may therefore be a fundamental difference between the two populations. Our results indicate that internal fixation may not be the best treatment for very elderly female patients with impacted or minimally displaced intracapsular fractures, and that male patients may have a better prognosis.

In our series, hemiarthroplasty for displaced fractures in very elderly patients gave better results in terms of reoperation rates than internal fixation for undisplaced fractures. The functional outcome after hemiarthroplasty has been shown to be equivalent to that of successful internal fixation in terms of pain and mobility (Skinner et al 1989) and we found no difference in pain incidence between our fixation and hemiarthroplasty groups. For very elderly patients, the preservation of the femoral head has a low priority; the avoidance of a second operation 
before full recovery from the primary procedure may be more important. Although hemiarthroplasty is a more extensive operation than internal fixation, our results suggest that the duration of the initial hospital stay and the early mortality rate are similar for the two surgical procedures.

Conclusions. Elderly female patients with minimally displaced fractures of the femoral neck should be treated either conservatively by mobilising the patient as soon as possible and performing hemiarthroplasty for secondary displacement or, when early mobilisation is essential, by a primary hemiarthroplasty.

No benefits in any form have been received or will be received from a commercial party related directly or indirectly to the subject of this article.

\section{REFERENCES}

Barnes R, Brown JT, Garden RS, Nicoll EA. Subcapital fracture of the femur: a prospective review. J Bone Joint Surg [Br] 1976; 58-B:2-24.

Bentley G. Impacted fractures of the femoral neck. J Bone Joint Surg [Br] 1968; 50-B:551-61.

Clark DI, Crofts CE, Saleh M. Femoral neck fracture fixation: comparison of a sliding screw with lag screws. J Bone Joint Surg [Br] 1990; 72B: $797-800$.

Evans JG, Wandless I, Prudham D. A prospective study of fractured proximal femur: hospital differences. Public Health 1980; 94(3): 149-54.
Freeman MAR, Todd RC, Pirie CJ. The role of fatigue in the pathogenesis of senile femoral neck fractures. J Bone Joint Surg [Br] 1974; 56B:698-702.

Garden RS. Low-angle fixation in fractures of the femoral neck. $J$ Bone Joint Surg [Br] 1961; 43-B:647-63.

Law MR, Wald NJ, Meade TW. Strategies for prevention of osteoporosis and hip fracture. $\mathrm{Br}$ Med J 1991; 303:453-9.

Martinez LM. Intracapsular femoral fractures: the challenge for the year 2000. In: EFORT Postgraduate Lectures. No 1. Paris: Masson, 1993:88-96.

Raaymakers ELFB, Marti RK. Non-operative treatment of impacted femoral neck fractures: a prospective study of 170 cases. J Bone Joint Surg [Br] 1991; 73-B:950-4.

Skinner P, Riley D, Ellery J, et al. Displaced subcapital fractures of the femur: a prospective randomised comparison of internal fixation, hemiarthroplasty and total hip replacement. Injury 1989; 20:291-3.

Strömqvist B, Hansson LI, Nilsson LT, Thorngren K-G. Hook-pin fixation in femoral neck fractures: a two-year follow-up study of 300 cases. Clin Orthop 1987; 218:58-62.

Swiontkowski MF, Hansen ST, Kellam JT. Ipsilateral fractures of the femoral neck and shaft: a treatment protocol. J Bone Joint Surg [Am] 1984; 66-A:260-8.

Swiontkowski MF, Harrington RM, Keller TS, Van Patten PK. Torsion and bending analysis of internal fixation techniques for femoral neck fractures: the role of implant design and bone density. $J$ Orthop Res $1987 ; 5: 433-44$.

Wood DJ, Ions GK, Quinby JM, Gale DW, Stevens J. Factors which influence mortality after subcapital hip fracture. J Bone Joint Surg [Br] 1992; 74-B:199-202. 